Valóságos könyvtár - könyvtári valóság. Könyvtár- és információtudományi tanulmányok 2018. Szerk. Kiszl Péter, Csík Tibor.

Budapest, ELTE BTK Könyvtár- és Információtudományi Intézet. 2018. 191-198.

\title{
TÉR, IDŐ, TARTALOM \\ KOR- ÉS HELYTÖRTÉNETI WEBPROJEKTJEINK ÚJABB TANULSÁGAI
}

\section{FODOR JÁNOS}

ELTE BTK KITI, egyetemi adjunktus

\section{TARTALMI ÖSSZEFOGLALÓ}

Korunk könyvtári fejlesztései kettős innovációt igényelnek: a technológiai lehetőségek és a korszerú könyvtári szemlélet adekvát interpretálását. Tartalomszolgáltatás-kutató múhelyünkben több olyan, szemléletében innovatív projektről számolhatunk be, amelyek technológiai rálátást és kreatív jártasságot biztosítanak az intézményünkben tanuló szakember jelölteknek. A könyvtárak Facebook-jelenlétével kapcsolatos kutatásunk bizonyította, hogy a legsikeresebb bejegyzések térrel, idővel kapcsolatos, továbbolvasható, gondosan kidolgozott információegyüttesek. Az identitás közös nevezőjére alapozva, a hely- és kortörténet senkitől sem idegen témájában lehet leghatékonyabban példát mutatni megosztott történettel, hozzáadott tudományos háttérinformációkkal, linkekkel kedvet teremteni az elmélyülésre, hasonló gyüjteménytételek önálló fölkutatására. Ezért áll múhelyünk érdeklődésének középpontjában olyan részgyújtemények, dokumentumegyüttesek webes kidolgozása, melyek hely- és kortörténeti kontextusa sikeresen felmutatható az oktatás keretei között, egy-egy félév hallgatókra elosztott munkájával.

A könyvtár tartalomszolgáltatási lehetôségeit kutató műhelyünk érdeklődésének fókuszába az ezredforduló óta a közösségi média került. A korábbi honlap-centrikus intézményi jelenlétben hinni hiábavaló ${ }^{1}$, vagy legalábbis illuzórikus, ha a felhasználók tájékozódási szokásai - a technológia változásának függvényeként - a közös felületek felé mutatnak. A közösségi hálózatokban megosztott tartalmak témáiban, és a kapcsolódó aktivitások - kommentekben és lájkokban tetten érhető - jeleiben két, markánsan eltérő magatartásforma tükröződik, melyekre a könyvtári tartalomfejlesztés hatékonyan reflektálhat.

\section{A biz̨tonságos kö̈ös nevezó bövitése}

Az egyik meghatározó attitűd a saját, óvott értékek rendezési igénye, kontrollja, a közösségi médiában bármely szinten és tudással, a közreadás és befogadás bármely öszszetételében jellemző biztonsági játék. A mai tizenévesek távolságtartása, elfordulása a Facebooktól éppen a gyors, radikális megoldás választásaként - a türelmetlenség jeleként - magyarázható az uralható kapcsolatrendszer igényével: ne szóljon és lásson bele kommunikációjába rokon, ismerősként ôt kiskorában bejelölt szülő. A fiatalok nem 
kívánnak maradandó portfóliót építeni élményeikből, eszük ágában sincs más korosztályok számára nyomokat hagyni, önfelszámoló üzenetekkel kommunikálnak inkább a Snapchat szolgáltatásban. Minél bonyolultabb a szolgáltatásrendszer - gyermeknek, kamasznak, a számítástechnikával idős korban ismerkedőnek - annál nehezebb átlátni a privátszféra védelmét többé-kevésbé biztosító beállítások lehetőségeit, s a közösségi hálón legotthonosabban mozgó huszonévesek életében változnak a legdinamikusabban az életkörülmények. Az ő életükben is jöhetnek tehát olyan időszakok, amikor rutinból, kevéssé odafigyelve posztolnak vagy kattintanak linkekre, akár vírust terjesztő üzeneteket szabadítva ismerőseikre.

Ahogy a közösségi média tartalmának hitelessége megkérdőjeleződik, a megosztási aktivitás mozgatórugói között egyre hangsúlyosabbá válik a személyes hitel fenntartása is. Az identitáslopás fenyegető lehetôsége vagy az online zaklatás gyakran tragikus esetei csak szélsőséges példák arra, mennyire könnyü lerombolni, s milyen nehéz megőrizni a magunkról fölépített virtuális képet, milyen nehéz azt újra érvényesíteni munkahelyben, életközegben vagy párkapcsolatban bekövetkező változások esetén.

A nehezen átlátható, sok tényezőtől függő rendszerekben a felhasználók alapélménye ezért az óvatosság, néhány alapszabály esetenként túlzott, görcsös betartása. Sokan kizárólag olvasásra, vagy csak lájkolásra, netán kommentelésre használják a Facebookot, saját képet sem töltenek fel. Tartalmak bevitele nélkül, valójában „,nem rendeltetésszerűen” használják a rendszert, sőt, ha úgy vesszük: bántóan „,kukucskálnak” csak, mások életét lesve, sajátjukról hallgatva. E magatartás egyre népszerűbb, hiszen passzív nézőként a profiljukhoz hozzáférők körének szabályozásával alig kell foglalkozniuk.

Az identitás védelme legalább ilyen meghatározó az aktív megosztók magatartásában is, hiszen a közösségi médiában komoly szerkesztő, publikáló munkát végzők akarva-akaratlanul, saját felelós kiadóikeá válnak. Az erőfeszítés értelme, a profit, amiért e munkát elvégzik, saját identitásuk formálása, megőrzése, fenntartása. A megosztások, az ízlést vagy állásfoglalást tükröző kedvelések és kommentek sorával önmagunkból írjuk a Facebook, Instagram stb. tartalmát, annak - legalábbis - ismeretségi hálónk számára olvasható részét. Folyamatosan döntési helyzetben vagyunk: mit és kinek tegyünk láthatóvá személyiségünk vonásaiból, életünk fejezeteiből.

A veszélyek mérlegelése és az identitás épségét óvó megfontolások a megosztott tartalmak összetételében, gyakoriságában tükröződnek. A mindenkire jellemző témák senkit se zavarnak, a rétegérdeklődésre számot tartó megosztások réteghatároló hatásúak. Ha képzeletben statisztikát készítünk egyéni Facebook-élményünkről, bízvást igazolva látjuk, hogy többé-kevésbé biztonsággal megoszthatóak az „itt jártam, ezt láttam, ezt ettem” típusú tartalmak, a „szelfik” és ,gasztrofotók”, hiszen mindenki jár itt vagy ott, a digitális fotózás mobiltelefonos korszakában pedig végletesen elfogadottá vált önmagunk és élményeink lépten-nyomon megörökítése. Ugyanígy közös nevező a mémek továbbosztása, a részvétel a komikum hullámhosszán kialakult közös szórakozásban. 
Csoportképző, elhatároló hatása miatt már kompromisszumokkal, de a többség számára még „bevállalhatóak” a nagyobb közösségekhez kapcsoló elköteleződések, a rajongott zenészek, rétegkultúrák, hobbi, életmód, netán politikai hovatartozás vállalásai. A magabiztosabb felhasználókat nem rettenti el a veszély, hogy néhány ismerôs esetleg elfordul tőle, vagy ellenérzéseit fejezi ki - a különbözőség tolerálása e tekintetben változó lehet.

Sokkal kockázatosabb azonban a mélyebb ismeretek, a szaktudás, a szúk rétegérdeklődés megosztása. Ha nem vagyunk a téma ismert szakértői, ám vannak ismerőseink között e területeken jártasak, nyilvánosan kiderülhet relatív tájékozatlanságunk, lelepleződhetnek bizonytalan forrásaink. Olyan ismerősöktől, akiket a téma nem érdekel, elválaszthat lelkesedésünk, számukra érdektelen megosztásaink sorozata.

A műveltség és elmélyült érdeklődés szükségszerűen szűrő. Önképző körök, klubok, internetes fórumok épülhetnek köré, de közösségi hálóból nincs alternatíva, ott ugyanazért jelent kockázatot fölvállalása, amiért a kiberzaklatás. Nincs más rétegzettség, csak a közeli és kevésbé közeli ismerősök egyaránt vegyes érdeklődésű skálája. Ha a közösségi hálón ismerősökkel is szívesen megosztott tartalmak tudományos „,mélységigényét” végig követjük, akkor a saját fotóktól, a szöveges közlésektôl és a blogokból, weblapokról megosztott cikkek, hírek tömegén keresztül szinte csak egyetlen, bár tágan értelmezhető témában, a kor- és helytörténet vonatkozásában juthatunk el a könyvtári tudáskincs mélységéig, hiteléig.

A közösen megélt idő előzményei és a közösen ismert tér múltja mindenkit érdekel. A web hálózatos információhalmaza mögül máig hiányzó kronológiai rétegzettség valamilyen szinten mindenkiben hiányérzetet kelt, s a térképes, navigációs alkalmazások sikere is látványosan bizonyította, hogy a „kibertér” absztrakt térélménye önmagában kevéssé bizonyult vonzónak.

A szkennelés, digitális fényképezés és a sávszélesség növekedés amatôr helytörténészek tömegét hozta a közösségi hálóra. E természetes igényként és retro mániaként is joggal azonosítható jelenség hátterében látnunk kell, hogy fedésbe kerül a közösségi weben önmagát képviselő író-olvasó biz̨tonságérzẹte - és a tudás forrásához közvetlenül hozzáférő könyvtár küldetése. A kockázatmentes megoszthatóság feltételeit teljesítik a hiteles információegyüttesek, tényként, biztos építőelemként használva, a könyvtárak, történeti fotógyűjtemények tételei kimeríthetetlen forrásaivá válnak visszapillantó múltidézések közös rácsodálkozást kiváltó megosztásainak.

De a könyvtári szereplehetőség nem pusztán a gyüjtemény elemeinek felkínálásában áll. Jelentheti a kutathatóság, a tudományos összefüggésrendszer népszerúsítését is. Az identitás közös pontjainak biztonságára alapozva, a hely- és kortörténet senkitől sem idegen témájában a legkönnyebb olyan megosztásokkal példát mutatni, amelyek kedvet teremtenek az elmélyülésre, továbbkutatásra, hasonló gyűjteménytételek önálló megtalálására.

Két ízben is lefolytatott ${ }^{2}$ közösségi média kutatásunk során a legnépszerúbb, legsikeresebb bejegyzések szinte kivétel nélkül térrel, idővel kapcsolatos, továbbgondol- 
ható, továbbolvasható, gondosan kidolgozott információegyüttesek voltak. Jó példa a Fővárosi Szabó Ervin Könyvtár (FSZEK) Budapest Gyűjteményének poszt-sorozata, amelyben képarchívum-tételeik megosztását mutatták be, inspiráló elhivatottsággal és csapatmunkával. A gyüjtemény vezetője, Sándor Tibor így emlékezett ${ }^{3}$ vállalkozásukra: „munkatársainkat elragadta a hév: a közléseket egyre igényesebb eseti kutatások előzték meg, a magyarázatok egyre hosszabbak lettek, magunk közül választott lektorunknak pedig kíméletlenül kellett csattogtatnia szerkesztői ollóját. A közlemények megírásában mindenki részt vett, beleértve raktárost, közmunkást és szerződéses önkénteseinket is."

A közösség aktivitása napjainkban többek között a lokálisan, személyes kötődések mentén értékes ismeretek felhalmozása felé mutat. A több országban népszerű Topotékák ${ }^{4}$ a kisebb régiók, városrészek lakóinak örömmel megosztott fotóiból, a múltat saját kötődéseikben feltáró emlékezésekből gyarapodnak, s válnak a helytörténet élő forrásaivá.

Egyetemi műhelyünk már a kétezres évek közepétől foglalkozik ${ }^{5}$ helytörténeti részgyưjtemények hálózati közreadási lehetőségeivel, modellkísérleteink legnépszerűbb megvalósult példái régi budapesti fotók közreadására épülnek.

Kalota Béla antikvárius, amatőr fotós csaknem ezer tételes képanyagára épült első hely- és kortörténeti projektünk, amely különösen népszerű volt hallgatóink körében. Az iTTiVoTT Budapest enciklopédikus módszerességgel rendszerezi több száz budapesti vendéglátóipari egység portálfotóit a rendszerváltás utáni évtizedből, a város valamennyi kerületéből. A projekt megvalósítása során a kocsmatérkép-jellegű kezdeményezéseket megelőzve, elsők között alkalmaztuk a helyszínek térképre helyezésének, linkelésének és beágyazásának lehetőségét. A „,retro képpárok divatjának” elterjedése előtt kezdtük el az „ilyen volt - ilyen lett” párhuzamok vizuális megjelenítését is, hiszen a projekt folytathatóságát és érdekességét kezdettől fogva az adja, hogy a gyújtemény helyszíneit pár évente felkeressük, s megörökítjük az üzlethelyiségek változását, funkcióváltását, fejlődését vagy lepusztulását.

Várostörténeti szempontból is tanulságos követni a Kalota Béla által megörökített helyszínek metamorfózisát pl. presszóból kínai üzletté, abból nemzeti dohánybolttá, s a helyszíneket személyesen ismerők számára emlékezetes idővonalat húznak a hallgatók által elkészített bejegyzések, helyszínleírások.

Az iTTiVoT'T projekt volt az első a műhelymunkáink közül, melyet a statikus gyűjteményi weboldalak mellett 2009-től a Facebook felületére is bevezettünk, és a létrehozott csoporthoz máig csatlakoznak érdeklődők. Sikerként könyvelhetjük el azt is, hogy a képgyűjtemény legrégebbi, Kalota Béla által készített rétege a Budapest múltjával foglakozó csoportok, honlapok kedvelt képforrásává vált.

Egyetemi projektjeinek sorában talán a legnagyobb, bár legkevésbé meglepő közönségsikert Neon Budapest gyűjteményünk ${ }^{7}$ hozta. A budapesti neonfények látványos mementói az elmúlt korszakoknak. Megmaradásuk, óvásuk sokak szívügye volt a rendszerváltás után. A projekt során egy pár évvel korábbi fotógyűjtemény tételeit, helyszíneit fotóztuk újra, létrehozva az időben érzékelhető változások lenyomatait, hiszen a törékeny 
TÉR, IDŐ, TARTALOM. KOR- ÉS HELYTÖRTÉNETI WEBPROJEKTJEINK...

városdíszek közül sok eltűnt, megrongálódott pár év leforgása alatt is. A szöveges helyszínrajzokkal és térképes ábrázolásokkal kiegészített tételeket több szempont alapján - így a hirdetés tartalma és a tevékenység aktualitása, a tipográfia, az elhelyezés és a felirat állaga, állapota szerint - szűrhetővé, rendezhetôvé tettük.

A projekt újdonságát a közreadás komplexitása, a háttéranyag sokfélesége és a bevont szakemberek, szakterületek gazdagsága adta. A korábbi neonmentő vállalkozásoktól a várostörténeti és technológiatörténeti visszatekintésig, a nemzetközi és vidéki körképtől a múvészeti és iparmúvészeti felhasználásig, a múzeumok nemzetközi áttekintésétől a neon hazai - még létező, kisipari - gyártásáig számos kapcsolódási pontot kínáltunk ahhoz, hogy a látogatók érdeklődését felkeltsük. A projektbemutatón e kapcsolódó területek több képviselője közremúködött, s a honlapra felfigyelt a média. A beszámoló cikkek és munkánkra hivatkozó publikációk száma folyamatosan gyarapodik, s rendszeresen kapunk visszajelzéseket, a gyüjteményből hiányzó neonfényeket figyelmünkbe ajánló leveleket.

\section{Igény a kontrollált kealandra}

A közösségi hálón megosztott tartalmakból és aktivitásokból kirajzolódik a virtuális biztonságra törekvés ellenpontja is, a kontrollált hazardírozás igénye. A közös identitást szolgáló, időben-térben emlékezetes élményekre nem csak visszaemlékezni, de azokat sajátunkként megélni is szeretnénk a jelenben, hogy később saját múltunk felidézhető részévé váljanak. Kínálhat-e élményt, egyszeri, jelenben átélt kalandot a könyvtár, melynek elsődleges funkciója a felhalmozott múlt elérhetővé tétele? A verseny nagy, a vetélytársak előnyben vannak, ám a digitalizált tartalmak szervezhetősége és dinamikus felhasználási lehetőségei új lehetôséget kínálnak a könyvtárak, memóriaintézmények számára is, ha elfogadják saját feladatként a létrehozott digitális tárak és az olvasók közötti közvetítést.

Alkattól függ, ki hogyan gondoskodik adrenalinszintje megemeléséről: a horrorfilm-nézéstől a túrázásig, a vadvízi evezéstől a siklóernyőzésig. De a szabadidős tevékenységekről árulkodó közösségi médiatartalmak alapján érzékelhető, hogy az óvott, védett identitás ellenpontja a kihivások vállalása. A kontrollált körülmények között, szolgáltatásként igénybe vett izgalmak, a sæabadulószobák, rejtélymegoldások és nyomozójátékok népszerűsége megfeleltethető a leterhelt menedzseréletmódból kiszakító extrémsportoknak, a munkaközösséget felrázó csapatépítő tréningeknek is. Az irányítottság és a játékos feladatokban boldogulás többségünknek meghatározó, jó emléke. Amikor az előkészített, váratlan izgalom kulturális és tudományos tartalommal párosítható, a résztvevők sajátjukként élik meg a tanulás folyamatát, s az így szerzett tapasztalatokat leghitelesebb, legmegbízhatóbb ismereteik között raktározzák el. Tudják ezt a pedagógusok, de tudja ma már sok, a közösségi médiában aktív, közismert vállalkozás (pl. Hosszuúlépés, járunk ${ }^{8}$ ), amely közösségi, személyesen átélhető kalandként kínál különleges, vagy keve- 
FODOR JÁNOS

sek által ismert helytörténeti programokat, sétákat, kirándulásokat. A siker kulcsa itt is az izgalom, a megismételhetetlen, egyszeri élmény ígérete.

Mind a valós, mind a virtuális gyújtemények igyekeznek tanulni a korunkra jellemző szabadidős tevékenységek példáiból. A „gamification” igénye, a játékélmény beemelése múzeumi tárlatrendezéstől a webes felületek tervezéséig számos formában aktuális téma új projektek tervezésekor. Évek óta ismertek a tartalomszolgáltatás és tájékoztatás megújításával kapcsolatos hazai kutatómúhelyek', a Hajnali háztetők helyszínének bejárhatóságát biztosító applikációtól ${ }^{10}$ a népszerū Fortepan fotógyūjtemény - egyszer talán megvalósuló ${ }^{11}$ - helyszín-nyomozós, újra fotózós kiterjesztéséig.

A kísérleti projektek és ötletek gyakran megelőzik korukat vagy befektető hiányában tervek maradnak. De, ahogy a digitális technológiák, algoritmizálható folyamatok alkalmazási lehetőségei megjelennek az egyes tudományterületeken, a rendszerezett ismeretek értékéről újabb és újabb izgalmas példákat mutathatunk föl. A digitális bölcsészet (hazánkban) friss tudományága kipróbált, kompatibilis eszközöket ad a kulturális örökség adatainak korszerű feldolgozásához és megjelenítéséhez, akár vizualizálásához. Térképen vagy infografikán ábrázolva vonzóbbá és befogadhatóbbá tehetôk a korábban csak hosszú tanulmányokban kifejthető összefüggések, pl. régmúlt korok kapcsolati hálói. Nyelvstatisztikai minták kiértékelése nem csak a számítógépes nyelvészet kutatásaiban alkalmazható, de digitális helyszinelésként akár egy elhunyt költő régi fájljaiban kutatva, életművének rekonstruálásában is. A tudomány élményszerű, rejtvényeket megfejtő arcát megmutatva, a tudományos tartalomszolgáltatás is több eséllyel versenghet a figyelemért, a kutatási vágy felkeltéséért.

Az izgalmas élményeket, a személyes kötődési lehetőséget és a szabad kutathatóságot a tartalomszolgáltatás alapötlete is biztosíthatja. A Budapest Gyüjteménnyel közös Hullámfürdő projektben mi is a közös nyomozás lehetőségét, motiválásának módjait kutatjuk: a rövidesen közzétett több mint félezer fényképen a 70 évvel ezelôtti Gellértfürdő vendégei, a kor elitjének képviselői láthatóak, a paparazzi-fotósok korszakát megelőző, szokatlanul intim beállításokban. A képeket az akkori fürdőmester, Pusztai Sándor saját örömére, olykor a modelleknek szánt ajándékként készítette. Bevontunk szakértő történészeket, de velük is csak a személyek 10\%-át tudtuk beazonosítani, jobbára azokat a színészeket, politikusokat, akiket egy korábbi válogatott kiállításra (Miniszterek gatyában, 2012 ${ }^{12}$ ) már kiválasztottak. A Budapest Gyűjteménnyel közösen kialakított koncepció szerint megpróbálunk megtenni mindent annak érdekében, hogy a gyüjtemény közösségi átvizsgálása, a nagy- és dédszülők azonosításának esélye a lehető legnagyobb legyen. A közösségi média terjesztéshez megosztható ízelítőként kollázsokat készítünk, melyek egy-egy közös motívum mentén válogatnak a bőséges képanyagból, felkeltve a figyelmet az érdekes részletekre. A gyüjtemény tételeit a lehetséges szempontok szerint szűrhetővé tesszük, s háttéranyagokat szerkesztünk a korabeli fürdőéletről, fürdőruha-divatról, a korszak eseményeirôl. A Hullámfürdôvel kapcsolatos visszajelzéseket űrlapon és saját Facebook-oldalon gyűjtjük majd, így elemezni, mérni tudjuk a projekt sikerességét. 
TÉR, IDŐ, TARTALOM. KOR- ÉS HELYTÖRTÉNETI WEBPROJEKTJEINK...

Tanulságok

Az ELTE egyetemi könyvtárosképzésében olyan kísérleti projektek során fejlesztjük hallgatóink digitális, informatikai kompetenciáit, amelyek reflektálnak a hálózati közegben visszavonhatatlanul megváltozott olvasási, tájékozódási szokásokra. Együttműködő partnereink segítségével élő, izgalmas tartalmakat fejlesztünk, s az egyetemünkön Intézetünk támogatásával létesülő Digitális Bölcsészet Központ ${ }^{13}$ múködésétől is további fejlődést remélünk. Projektjeink tanulságai alapján a könyvtárosság és a könyvtártudomány hálózati tájékoztató aktivitásának új területe, vagy a meglévő új vetülete rajzolódhat ki. Fontosnak érezzük jelezni, hogy a digitalizálással nem ér, nem érhet véget a könyvtár felelôssége a rá bízott tartalmak közvetítésében. Szükséges a kreatív, közvetítő magatartás és az ezt lehetővé tévő kompetenciák fejlesztése. Lehet, hogy e kompetenciák a médiatudomány területével átfedésben vannak, ám interdiszciplináris tudományterületünket ismerve, ez a kapcsolódás korántsem váratlan, vagy idegen számunkra, s adekvát módon illeszkedik a könyvtár jövőképét felvázoló elméletekbe is.

\section{Jegyzetek és irodalom}

1. FODOR János: Könyvtári szereplehetőségek a közösségi médiában. = Könyvtári Figyelő, 61. évf. 4. sz. 2015. 481-485. p.

2. FODOR János: Megosztás vagy szerkesztés? A könyvtár változó szerepe a közösségi médiában. = Tudományos és Múszaki Tájékoztatás, 64. évf. 1. sz. 2017. 24-36. p.

3. SÁNDOR Tibor: Helyismeret változó felhasználói környezetben. A százéves Budapest Gyújtemény mai törekvései. = Könyvtári Figyelő, 61. évf. 2. sz. 2015. 157-167. p.

4. A Topotékákról a Wikipédián: Forrás: https://hu.wikipedia.org/wiki/Topot\%C3\%A9ka [2017. november 27.]

5. FODOR János: Kollaboratív tartalomfejlesztési projektek az ELTE BTK Könyvtár- és Információtudományi Intézetében. = Tudományos és Műszaki Tájékoztatás, 62. évf. 11-12. sz. 2015. 429-441. p. Forrás: https://tmt.omikk.bme.hu/tmt/article/viewFile/607/575 [2018. július 27.]

6. iTTiVoTTT Budapest [honlap] Forrás: http://inaplo.hu/ittivott [2017. november 27.]

7. Neon Budapest [honlap] Forrás: http://inaplo.hu/neon/ [2017. november 27.]

8. Hosszúlépés, járunk? [honlap] Forrás: https://hosszulepes.org/hu [2017. november 27.]

9. MOME TechLab [honlap] Forrás: http://create.mome.hu/ [2017. november 27.]

10. Interaktív irodalmi séta Ottlik Géza Hajnali háztetők című regényének városi kalandtúra jellegú élmény formájában való feldolgozásával a Petőfi Irodalmi Múzeummal és az MTA SZTAKI-val együttműködésben. Forrás: techlab.mome.hu/hajnalihaztetok [2017. november 27.]

11. „Nem érzem idealizmusnak, szerintem ez a normális” - Tamási Miklós, Fortepan. = artportal.hu 2017-07-17. Forrás: https://artportal.hu/magazin/nem-erzem-idealizmusnakszerintem-ez-normalis-tamasi-miklos-fortepan [2017. november 27.] 


\section{FODOR JÁNOS}

12. Miniszterek gatyában - Pusztai Sándor úszómester képei 1930-1939. = Mai Manó Ház, 2012. 05. 13. Forrás: http://maimanohaz.blog.hu/2012/05/13/miniszterek_gatyaban [2017. november 27.]

13. ELTE.DH - Digitális Bölcsészet Központ - Eötvös Loránd Tudományegyetem [honlap] Forrás: http://elte-dh.hu/hu [2017. november 27.]

Fodor János egyetemi adjunktus és a hálózati jelenlét felelőse az ELTE BTK Könyvtár- és Információtudományi Intézetben. Kutatási területe: digitális gyújtemények a kultúra területén, könyvtári aktivitás a közösségi médiában, a web 2.0 és a mobil hálózatiság társadalmi hatásai. 